\title{
COLLEGE STUDENT PERCEPTIONS OF E-TEXTBOOKS AND E-READERS: NEW WAYS TO LEARN?
}

\author{
Gayle R. Jesse,gjesse@liberty.edu
}

\begin{abstract}
E-textbooks provide flexibility for individuals, especially college students, when purchasing textbooks for college classes. The purpose of this study is to determine if e-textbooks affect college student learning. However, additional research questions must be answered: what percentage of college students is purchasing e-textbooks? Do college students prefer using e-textbooks to a print/physical textbook (p-textbook)? Will e-textbooks replace p-textbooks within the next five years? Does owning an electronic reader affect student learning? Answering these five research questions, as well as three additional questions, involved comparing data collected via survey from 395 students at two academic institutions during the Spring 2013 semester. This explanatory study yielded five significant findings; however, the main result concluded that 37\% of college students feel e-textbooks have a positive effect on their learning and $41 \%$ state no difference on the effect of their learning. Overall, the research in this study should be used to inform the information systems community and individuals working in education because students' study habits will change dramatically within the next five years. These changes result from the majority of students owning an e-reader, purchasing e-textbooks, and the positive impact these two technologies has on education.
\end{abstract}

Keywords: Digital Book, Electronic Readers, E-Readers, E-Textbooks, E-Books, Tablet PCs, College Students

\section{INTRODUCTION}

The proliferation of digital reading devices has reached a critical point. Frequently, people using an e-reader or a tablet PC (TPC) are reading a digital book because digital books or e-books are swiftly becoming a trend and not just a fad. Weber [24] reported that BiblioTech, the first bookless public library system in the country, opened in September 2013 in San Antonio, Texas. This $\$ 2.3$ million library does not contain books on shelves, but rather rows of iMacs and iPads. Patrons of the BiblioTech bookless library can check out iPads loaded with five books, and residents of Bexar County are taking full advantage of the many resources this bookless library offers.

Abram [1] stated that textbooks are one of the more exciting arenas for e-books; however, people tend to think they can simply make a traditional textbook into an e-book and place it on the web or a TPC. Textbooks, though, need to be understood as more than just a simple vessel of content. Textbooks typically function as the framework for the entire pedagogy of a course, a grade, or a content area. Most textbooks are revised over many years via editions to update subject matter from industry experts, teachers, and editors with publishing talent. Furthermore, textbooks are connected to curriculum development or professional standards; educators and students utilize them in a shared learning environment. The learner experiences the pedagogy in a phase framework, wherein one piece of knowledge, skill or competency is completed in preparation for learning the next highest competency. Additionally, the authors consider diverse learning styles, target audiences, and age/stage issues when textbooks are designed.

Individuals can use e-books and TPCs to save money, enhance education, and advance literacy if they can accept the technology. The researcher contends that Davis' [7] Technology Acceptance Model (TAM) can be directly applied to an individual's decision to purchase an e-reader or TPC because TAM theoretically conceptualizes how individuals decide to accept and use a technology. In short, Davis' [7] TAM, found in Appendix B, suggests that when individuals are offered a new technology, several factors can influence their decision about how and when they will use it. Davis [7] defined Perceived Usefulness (PU) as "the degree to which a person believes that using a particular system would enhance his or her job performance." Additionally, Davis [7] defined Perceived ease-of-use (PEOU) as "the degree to which a person believes that using a particular system would be free from effort." Haag [9] has titled the current generation of technology users as "screenagers" because they spend so much time in front of a technology screen. While TAM points to an individual's purchase decision based on PU and PEOU, Haag [9] has argued that the current generation of users has already accepted screens and TPCs have a PEOU. This study does not examine whether or not the current generation feels TPCs also possess PU, but the author does suggest that this would be an excellent future study to conduct. 


\section{LITERATURE REVIEW}

\section{Definition of E-book}

Manley and Holley [13], in their article titled "History of the Ebook: The Changing Face of Books," found the word $e$-book carries multiple meanings that depend upon context. For the purpose of this study, the researcher elected to use Hawkins' [10] definition of an e-book: "any book made available in electronic form through four different methods: a downloadable, dedicated e-book; a dedicated e-book reader; a web accessible e-book; or a print-ondemand book." The researcher used the online version of the Oxford English Dictionary (OED Online) to define ereader, tablet computer and tablet PC.

- E-reader - A hand-held electronic device used for reading e-books or other text in digital form. In the United States, e-reader is a proprietary name for software relating to electronic books. OED Online [17]

- Tablet Computer - A computer in the form of a flat tablet; especially one that accepts input through a stylus or a fingertip. OED Online [18]

- Tablet PC - A tablet computer is one that runs a version of the operating system of an ordinary personal computer (PC). OED Online [19]

The terms e-reader, tablet computer, and tablet PC (TPC) will be used interchangeably throughout the paper.

\section{History of E-Readers and E-Books}

E-books and e-readers are popular in contemporary society; however, at what point in history did this popularity commence? The idea of an e-book initiated with Vannevar Bush in 1945 when he published the article "As we may think;" however, Manley et al., [13] stated that the rough draft of this article was actually in 1930 titled "Mechanization and the record." The history of e-books and e-readers is substantial; therefore, to simplify the lengthy history, the following brief timeline of e-books and e-readers developed by Google Editions [8] has been provided.

- 1971: Michael S. Hart launched Project Gutenberg (PG). He created an e-book by typing the US Declaration of Independence into a computer. The purpose of Project Gutenberg was to create electronic copies of more books.

- 1992: Sony launched Data Discman, the first electronic reader

- 1998: First sales of e-book readers recorded, including the Rocket eBook, SoftBook, and the Cybook.

- 1999: Websites began selling e-books in English, such as eReader.com and eReads.com.

- 2010: Amazon announced that e-book sales outnumbered hardcover sales for the first time ever.

\section{E-books and Students}

Screenagers (current generation of users) are comfortable working with and reading from the TPC medium. Research conducted by Healy [11] found most elementary students feel that a thick paper book is intimidating, overwhelming and outdated. Moreover, when elementary students read from an electronic format they typically became more engrossed in reading books. Daniel and Woody [6] elucidated a significant positive and negative outcome to e-textbooks in "E-textbooks at what cost? Performance and use of electronic v. print texts." More time is spent reading when using electronic texts without the benefit of additional learning, and learning outcomes are achievable in this medium. Daniel and Woody [6] also suggested that the "challenge will be to design a more efficient and productive learning experience that leverages the positive aspects of the medium while minimizing some of the hurdles... and how e-textbooks can be designed to most efficiently maximize learning in this medium." The researcher agrees that the design of both e-textbook and e-readers must maximize learning to have a positive impact.

The Almanac of Higher Education [2] published a study conducted in 2011 and 2012 by Book Industry Study Group Inc. (BISG). In 2011, BISG received 625 responses and in 2012588 responses for a project titled "College Students' Attitudes about e-textbooks" and found that "slightly more than a quarter of college students had purchased a digital textbook for any course in the previous two years, and many reasons were given for preferring print." BISG asked college students if they would prefer to obtain all their textbooks in digital form; results indicated that in $201246.6 \%$ of the respondents either chose "strongly disagree" or "disagree" and 42.3\% chose 
"agree" or "strongly agree" to a preference for textbooks in a digital format. Additionally, BISG asked students about the their satisfaction with digital textbooks, and $89.4 \%$ of respondents were either "somewhat" or "very satisfied" and only $10.6 \%$ were "not at all satisfied." The reasons for preferring digital or print books as surveyed by BISG are displayed in Table 1.

Table 1. Reasons for Preferring Digital or Print Books

\begin{tabular}{|l|l|}
\hline \multicolumn{2}{|c|}{ Reasons for preferring digital } \\
\hline Easy search and reference & $52.6 \%$ \\
\hline Costs less than print & $48.5 \%$ \\
\hline Easy to carry around & $50.0 \%$ \\
\hline Can be obtained more quickly & $47.4 \%$ \\
\hline More convenient & $46.9 \%$ \\
\hline Allows interaction with content & $43.9 \%$ \\
\hline Can integrate with other content & $35.7 \%$ \\
\hline Can try out before buying & $30.1 \%$ \\
\hline Environmentally friendly & $35.7 \%$ \\
\hline
\end{tabular}

\begin{tabular}{|l|l|}
\hline \multicolumn{2}{|c|}{ Reasons for preferring print } \\
\hline Prefer look/feel of print & $52.0 \%$ \\
\hline Easier to bookmark & $43.8 \%$ \\
\hline No buyback with digital & $34.6 \%$ \\
\hline Lose access to digital content at end of semester & $34.3 \%$ \\
\hline Poor experience with digital & $16.7 \%$ \\
\hline Limits to sharing/copying digital material & $20.9 \%$ \\
\hline Don't have device & $20.9 \%$ \\
\hline Digital doesn't have enough advantages over print & $28.4 \%$ \\
\hline Privacy concerns & $13.4 \%$ \\
\hline
\end{tabular}

In 2001, Simon [22] determined that in order for e-books to gain widespread acceptance as an educational tool, they must reproduce the many easy-to-use features of a printed book and offer features of considerable value to college students, such as the ability to store large amounts of material, high-quality screens with backlighting for reading in varied situations, and a lightweight and easy-to-use design. Furthermore, in 2011, Paxhia [20] established that the order of important features by college students is ranked as follows: affordable (acceptable price range) 83\%; readable (easy on the eyes, adjustable font) 75\%; portable (easy to carry, transport, and download) 74\%; acquisition (easy to download or stream) 73\%; and, speed (instant access to book) $71 \%$.

\section{E-books and TPCs for Learning Institutions and Textbook Companies}

Mealer, Morgan, and Williams [14] conducted a study in 2011 at the University of Alabama titled "eReaders in Higher Education." Their executive summary contained several notable highlights for higher education institutions considering the adoption of TPCs.

1. Institutions building a digital library should make copyright considerations a high priority.

2. Faculty will need to abide by fair use principles including course reserve materials and take full advantage of publishing and distribution opportunities through the use of simple conversion software and e-Readers.

3. Format compatibility must be considered in relation to the curriculum the e-Reader will support.

4. Digital Rights Management (DRM ) technology prevents cross-compatibility for many types of files.

5. By law, only ADA-compliant devices may be required or recommended in the classroom; the instructor can make provisions that are equally beneficial for students with disabilities.

6. Colleges and universities should carefully consider the switch to e-Readers.

7. E-readers address issues with print textbooks, including current information, economy and accessibility.

\section{Advantages \& Disadvantages of Print Books and E-books}

Abram [1] and Blackwell [3] conducted a substantial amount of research on the advantages and disadvantages of print books and e-books. Therefore, the researcher constructed Table 2 and Table 3 to condense the key findings. Both tables list and explain a few notable advantages of using print books, e-books and e-readers from the student perspective. 
Table 2. Advantages of Print books

\begin{tabular}{|l|l|}
\hline \multicolumn{2}{|c|}{ Print Books } \\
\hline Availability & Not all books are available as e-books. \\
\hline Damage & $\begin{array}{l}\text { Dropping a print book does not cause a lot of damage. } \\
\text { Dropping an E-reader can cause damage; e-readers are more susceptible to damage }\end{array}$ \\
\hline Easier to Read & Paper books are easier to read. Contrast typesetting is not like reading from paper. \\
\hline Cost & Used books cost less. \\
\hline Sharing & Easy to share your own copy of the print book. \\
\hline Hardware/Software & Print book do not have faults in hardware or software \\
\hline Data loss & E-book readers may malfunction and data loss can occur. \\
\hline Readable & Print books remain readable for many years; e-books may need to be copied over time. \\
\hline Privacy & $\begin{array}{l}\text { Print books are private. } \\
\text { E-books can easily track data, times, usage, pages and details about what one is reading and } \\
\text { how often; no permanent digital trail of personal reading habits online. }\end{array}$ \\
\hline Safety & Print books cannot contract an electronic virus. \\
\hline Charging & Print books never turn off; e-reader batteries require recharging. \\
\hline Look \& Feel & $\begin{array}{l}\text { E-books cannot provide the physical feel of the cover, paper, binding of the original printed } \\
\text { work, or smell; some learning styles require the touch and smell experience; research } \\
\text { supports smell as a component in memory. }\end{array}$ \\
\hline Green & $\begin{array}{l}\text { Print books are biodegradable. } \\
\text { E-readers require various toxic substances to produce and are non-biodegradable. }\end{array}$ \\
\hline
\end{tabular}

Table 3. Advantages of E-books

\begin{tabular}{|c|c|}
\hline \multicolumn{2}{|r|}{ E-books \& E-readers } \\
\hline Instant Availability & E-books are instantly available for download and do not go "out of print." \\
\hline Language Translation & E-books can be easily translated into many different languages. \\
\hline Customizable Displays & E-book print can be changed to match personal needs; every learner has preferences. \\
\hline ADA Compliance & $\begin{array}{l}\text { Read-aloud can be done privately (headphones) or in a shared way among parent and } \\
\text { child or teacher and pupil; removes boundaries for sighted and visually challenged } \\
\text { readers; transfers content and learning experiences beyond simple text literacy. }\end{array}$ \\
\hline Reading Support & $\begin{array}{l}\text { E-readers enhance learning support; learning styles are supported through the } \\
\text { engagement with the interactive environment of an e-book; disabilities are overcome } \\
\text { through page and font layout changes or by combining text reading with auditory } \\
\text { stimuli. }\end{array}$ \\
\hline Making \& Taking Notes & Opportunity for the scholar to engage in reading and recreational reader for book clubs. \\
\hline Book Bags & $\begin{array}{l}\text { Medical concerns due to the weight of a backpack; e-readers can contain thousands of } \\
\text { books in mere ounces (limited only by memory capacity); content and experiences } \\
\text { related to the mere book can also be loaded or linked. }\end{array}$ \\
\hline Citation Support & $\begin{array}{l}\text { Citations are collected in proper format for research and can keep track of knowledge } \\
\text { gained for citation and bibliography purposes; assists students in integrating ethical } \\
\text { information practices seamlessly into their reading, learning and research. }\end{array}$ \\
\hline Educational Support & $\begin{array}{l}\text { Did the student read extended readings, visit recommended websites, or complete } \\
\text { assignments? Professors, teachers, or tutors can know how much content was viewed; } \\
\text { e-books allow for the insertion of test questions, exercises, journals, surveys, } \\
\text { collaboration software and more. }\end{array}$ \\
\hline Twitter \& Facebook & $\begin{array}{l}\text { E-readers integrate social media; students can share quotes, insights, opinions, and } \\
\text { reviews with their "tweeps," "FB friends" and classmates. }\end{array}$ \\
\hline Dictionary Function & $\begin{array}{l}\text { Increase vocabulary without interrupting the process of reading; one tap on a word and } \\
\text { the student gets a definition and a better understanding of the author's intent; reduces } \\
\text { the low vocabulary barrier for readers. }\end{array}$ \\
\hline Green & $\begin{array}{l}\text { Save hundreds of trees by reading e-books, newspapers and magazines; deleting an e- } \\
\text { book leaves no post-consumer waste. }\end{array}$ \\
\hline
\end{tabular}




\section{Cost}

While reviewing the literature, the researcher discerned a significant theme: cost. Therefore, while cost was not surveyed in this study, the researcher found it imperative to discuss. Carr's [5] 2013 study demonstrated that institutions and the marketplace must first remove the cost barrier that exists in today's paper textbook market, and it was also determined that if e-textbooks can deliver cost savings, students and faculty are interested. Additionally, Roscorla [21] noted in 2013 that both students and faculty cited cost as the primary factor when considering digital textbooks. Paxhia [20] stated in 2011 that e-books increased spending; however, Healy [11] contended in 2010 that e-books were less costly for college students. Furthermore, Brittany [4] in 2012 summarized a two-year study conducted by Daytona State College, which determined that students purchasing e-textbooks only saved $\$ 1$ when compared to students who bought traditional books, and many students still preferred paper books. Snodgrass [23] offered, "in 2011, [the] Educause Center for Analysis and Research (ECAR) conducted a student technology study titled 'National Study of Undergraduate Students and Information Technology' and it noted that e-books are cheaper than regular hardbound textbooks, easier to carry around and more accessible all the time." Finally, Murray and Perez [16] commented in 2011, "until e-textbook and format features are standardized and business models generate sizable cost savings e-textbook adoption is likely to adopt slowly" The literature review on cost concludes that research on the issue of e-textbooks and students' cost savings is fragmented. Historically, e-textbooks were introduced in the marketplace at a lower cost point; however, it now seems costs are increasing. Due to the increasing sales of e-textbooks, traditional textbooks sales decreased; therefore, publishing companies had to raise the cost of e-textbooks to cover operating expenditures.

The literature review on the usage of e-textbooks and e-readers indicated a ripe potential for a paradigmatic shift in the way the world reads and learns. Abram [1] summarized that e-textbooks need to address the environmental changes and the pedagogical implications for learning; moreover, if this shift in learning is not examined, then textbook companies are being complacent and unresponsive. E-textbooks need to embrace the many opportunities this medium has to offer. The e-learning experience should be enhanced in e-books or there is the possibility for missed learning opportunities. Finally, as Moore [15] noted, legislation passed in 2010 by the state of California requires all publishers to offer electronic versions of their textbooks for California universities by 2020 . In light of these insights, compelling needs emerged to research and understand the developments and perceptions of new technologies by and for the information systems community.

\section{METHODOLOGY}

\section{Research Design}

"This explanatory study was designed utilizing quantitative methods. Conducting this quantitative study involved administering a survey in three phases. The first phase consisted of developing a survey instrument. The second phase included testing with a pilot study involving one Thiel College student, which determined the time needed to complete the survey. Finally, the third phase entailed distribution to traditional college-aged Thiel College and Robert Morris University students. The survey research maintained an objective approach. Four software products were used: Moodle Learning Management System, e-mail, SurveyMonkey, and Microsoft Excel” Jesse [12].

\section{Participants}

This study involved two target populations: Thiel College (TC) and Robert Morris University (RMU). Both institutions were used as a convenience sample. The survey was distributed to the entire Thiel College population, while only students in the School of Communications and Information Systems at Robert Morris University were asked to complete the survey. At RMU, the School of Communications and Information Systems consists of the following five departments: Communications, Computer and Information Systems, English Studies and Communications Skills, Organizational Leadership, and Media Arts. Thiel College (Greenville, PA) and Robert Morris University (Moon Township, PA) are both located in western Pennsylvania about 70 miles apart. The participation statistics are listed in Appendix A, which provides the Spring 2013 enrollment statistics for both schools. The response rate was approximately $30 \%$ at TC and $11 \%$ at RMU, averaging a $21 \%$ response rate. 
Survey participants volunteered to respond by clicking on a SurveyMonkey link distributed via three e-mails sent by the researcher (professor recruitment). Eligible participants were at least 18 years old and enrolled at Thiel College or Robert Morris University. Engaging participants from the entire Thiel College population reflected a true representation of the college's student body across multiple majors and their views on e-readers and e-textbooks. However, due to time constraints, only students in the School of Communications and Information Systems at Robert Morris University were invited to complete the survey.

\section{Survey Instrument}

"The survey was conducted via surveymonkey.com link. The survey instrument developed for this study was derived from multiple sources and included both validated (surveymonkey.com) and non-validated questions (author created). The initial survey was divided into the following six sections: Consent Form; Demographic Information; Social Media; Smart Phones; E-Readers \& E-Textbooks; Thank you" Jesse [12]. While the survey instrument covered three main sections, Social Media, Smart Phones, and E-Readers \& E-Textbooks, only the E-Readers \& ETextbooks results are considered in this paper.

\section{RESEARCH QUESTIONS}

TPC technology has caused a dramatic shift in reading habits. Individuals transitioned from reading p-books to ebooks approximately five years ago, but within the past two years this shift has grown exponentially. From an educational perspective, the researcher evaluated how this shift in reading habits has and will potentially impact higher education. Therefore, this study had four objectives: determine if college students are buying e-textbooks, if tablets help with education, if e-textbooks will replace physical textbooks within the next five years, and if students prefer e-textbooks to p-textbooks. The information and research presented in the Literature Review section, in conjunction with the administration of a survey described in the Methodology section, provided insights to answer eight Research Questions (RQ).

\section{Research Questions}

The purpose of this study was to determine if e-textbooks affect college student learning. The eight research questions to be answered are as follows:

RQ1: What percentage of college students have purchased an e-textbook?

RQ2: Do students purchase e-textbooks for use on their laptops over a tablet?

RQ3: Do students feel e-textbooks have a positive effect on their learning?

RQ4: What percentage of college students feels tablets are valuable for education purposes?

RQ5: Do students feel tablets help them study more efficiently?

RQ6: Do students feel tablets help them perform better in their classes?

RQ7: What percentage of college students feels using tablets to hold their textbooks will replace physical textbooks within the next five years?

RQ8: What percentage of students that owns a tablet prefers using an e-textbook over a physical textbook?

\section{DATA ANALYSIS AND DISCUSSION}

Microsoft Excel software was utilized to calculate the percentage-based statistics reported in this study; all results exclude the system missing responses and $(\mathrm{N}=\mathrm{XXX})$ represents the number of responses. Appendix A contains the demographic statistics of age, gender, race, grade point average (GPA) on a 4.0 scale, and college majors reported in 2013 from both Thiel College (TC) and Robert Morris University (RMU). The survey results are displayed in two ways: percentage for each school and average percentage between the two institutions. The average percentage between the two institutions was calculated by adding the TC and RMU percent together and then dividing the answer by two. The researcher determined that calculating the average percentage between the two institutions reflected the best overall statistical survey findings for the information systems community. Therefore, Tables 4-11 display the response percentages and average percent between the two learning institutions. 
RQ1: What percentage of college students have purchased an e-textbook? The data indicated an average of $34 \%$ have purchased an e-textbook at the two institutions, which means the majority are not buying e-textbooks. However, when separating the TC data from the RMU data, the RMU data results suggest the majority is purchasing e-textbooks.

Table 4. RQ1: Percentage of college students that have purchased an e-textbook

\begin{tabular}{|c|c|c|c|}
\hline $\begin{array}{l}\text { Have you purchased an e-Textbook (digital) for a class to use } \\
\text { on your PC/Laptop or "Tablet" Computer? }\end{array}$ & $\begin{array}{c}\text { TC } \\
(\mathrm{N}=275)\end{array}$ & $\begin{array}{c}\text { RMU } \\
(\mathrm{N}=95)\end{array}$ & $\begin{array}{c}\text { Average } \\
(\mathrm{N}=370)\end{array}$ \\
\hline Yes & $25.80 \%$ & $42.10 \%$ & $33.95 \%$ \\
\hline No & $74.20 \%$ & $57.90 \%$ & $66.05 \%$ \\
\hline
\end{tabular}

RQ2: Do students purchase e-textbooks for use on their laptop over a tablet? RQ2 found that $55 \%$ of college students primarily use e-textbooks on their laptop.

Table 5. RQ2: Students purchase e-textbooks for use on their laptops over a tablet

\begin{tabular}{|l|r|c|c|}
\hline $\begin{array}{l}\text { If you answered yes to the previous question (purchased an e- } \\
\text { textbook), which technology device did you primarily use } \\
\text { your e-textbook on? }\end{array}$ & $\begin{array}{c}\text { TC } \\
\text { (N=71) }\end{array}$ & $\begin{array}{c}\text { RMU } \\
\text { R=39) }\end{array}$ & $\begin{array}{c}\text { Average } \\
\text { (N=110) }\end{array}$ \\
\hline Tablet & $25.40 \%$ & $28.20 \%$ & $26.80 \%$ \\
\hline Laptop/PC & $60.60 \%$ & $48.70 \%$ & $54.65 \%$ \\
\hline Both Equally (Tablet \& Laptop/PC) & $12.70 \%$ & $23.10 \%$ & $17.90 \%$ \\
\hline Not Sure & $1.40 \%$ & $0.00 \%$ & \\
\hline
\end{tabular}

RQ3: Do students feel e-textbooks have a positive effect on their learning? The researcher discovered $37 \%$ of respondents feel that e-textbooks had a positive effect on learning and $42 \%$ did not discern a difference. Although the percentage does not exceed the 50\% majority, the researcher surmised that e-textbook usage did not change students' learning and may elicit a positive response, since only $19 \%$ felt e-textbooks had a negative effect.

Table 6. RQ3: Students feel e-textbooks have a positive effect on their learning

\begin{tabular}{|l|c|c|c|}
\hline $\begin{array}{l}\text { What type of effect did using an e-textbook have on your } \\
\text { learning? }\end{array}$ & $\begin{array}{c}\text { TC } \\
(\mathrm{N}=70)\end{array}$ & $\begin{array}{c}\text { RMU } \\
(\mathrm{N}=39)\end{array}$ & $\begin{array}{c}\text { Average } \\
(\mathrm{N}=109)\end{array}$ \\
\hline Positive & $35.70 \%$ & $38.50 \%$ & $37.10 \%$ \\
\hline Negative & $17.10 \%$ & $20.50 \%$ & $18.80 \%$ \\
\hline Same/did not notice a difference & $41.40 \%$ & $41.00 \%$ & $41.20 \%$ \\
\hline Not Sure & $5.70 \%$ & $0.00 \%$ & \\
\hline
\end{tabular}

RQ4: What percentage of college students feels tablets are valuable for education purposes? This study found $73 \%$ of college students feel tablets are valuable for education purposes.

Table 7. RQ4: Percentage of college students feels tablets are valuable for education purposes

\begin{tabular}{|l|c|l|l|}
\hline Do you feel tablets are valuable for educational purposes? & $\begin{array}{c}\text { TC } \\
(\mathrm{N}=270)\end{array}$ & $\begin{array}{c}\text { RMU } \\
(\mathrm{N}=93)\end{array}$ & $\begin{array}{c}\text { Average } \\
(\mathrm{N}=363)\end{array}$ \\
\hline Yes & $69.30 \%$ & $76.30 \%$ & $72.80 \%$ \\
\hline No & $11.90 \%$ & $7.50 \%$ & $9.70 \%$ \\
\hline Not sure & $18.90 \%$ & $16.10 \%$ & $17.50 \%$ \\
\hline
\end{tabular}

RQ5: Do students feel tablets help them study more efficiently? The data indicated $47 \%$ of college students feel tablets help them study more efficiently.

Table 8. RQ5: Students feel tablets help them study more efficiently

\begin{tabular}{|l|c|c|c|}
\hline Do you feel tablets help students study more efficiently? & $\begin{array}{c}\text { TC } \\
(\mathrm{N}=271)\end{array}$ & $\begin{array}{c}\text { RMU } \\
(\mathrm{N}=93)\end{array}$ & $\begin{array}{c}\text { Average } \\
(\mathrm{N}=364)\end{array}$ \\
\hline Yes & $48.30 \%$ & $46.20 \%$ & $47.25 \%$ \\
\hline No & $24.00 \%$ & $22.60 \%$ & $23.30 \%$ \\
\hline Not sure/Undecided & $27.70 \%$ & $31.20 \%$ & $29.45 \%$ \\
\hline
\end{tabular}

RQ6: Do students feel tablets help them perform better in their classes? The researcher discovered $40 \%$ of college students believe tablets help them perform better in their classes. 
Table 9. RQ6: Students feel tablets help them perform better in their classes

\begin{tabular}{|l|c|c|c|}
\hline $\begin{array}{l}\text { Do you believe that tablets help students perform better in } \\
\text { their classes? }\end{array}$ & $\begin{array}{c}\text { TC } \\
(\mathrm{N}=270)\end{array}$ & $\begin{array}{c}\text { RMU } \\
(\mathrm{N}=93)\end{array}$ & $\begin{array}{c}\text { Average } \\
(\mathrm{N}=363)\end{array}$ \\
\hline Yes & $44.10 \%$ & $36.60 \%$ & $40.35 \%$ \\
\hline No & $24.80 \%$ & $26.90 \%$ & $25.85 \%$ \\
\hline Not sure/Undecided & $31.10 \%$ & $36.60 \%$ & $33.85 \%$ \\
\hline
\end{tabular}

RQ7: What percentage of college students feels using tablets to hold their textbooks will replace physical textbooks within the next five years? The data revealed $59 \%$ of college students feel tablets will hold their textbooks and replace physical textbooks with the next five years.

Table 10. RQ7: Percentage of college students that feels using tablets to hold their textbooks will replace physical textbooks within the next five years?

\begin{tabular}{|l|c|c|c|}
\hline $\begin{array}{l}\text { Do you feel tablets will replace textbooks, as we now know } \\
\text { them within the next five years? }\end{array}$ & $\begin{array}{c}\text { TC } \\
(\mathrm{N}=271)\end{array}$ & $\begin{array}{c}\text { RMU } \\
(\mathrm{N}=93)\end{array}$ & $\begin{array}{c}\text { Average } \\
(\mathrm{N}=364)\end{array}$ \\
\hline Yes & $62.40 \%$ & $54.80 \%$ & $58.60 \%$ \\
\hline No & $26.20 \%$ & $31.20 \%$ & $28.70 \%$ \\
\hline Not sure & $11.40 \%$ & $14.00 \%$ & $12.70 \%$ \\
\hline
\end{tabular}

RQ8: What percentage of students that owns a tablet prefers using an e-textbook over a physical textbook? The surveys found $36 \%$ of students preferred using an e-textbook on their tablet instead of a physical textbook. Although the average percent was low for both institutions, 44\% of RMU students preferred using an e-textbook, which is very close to the majority of students preferring e-textbooks on their tablets.

Table 11. RQ8: Students that own a tablet prefer using an e-textbook to a physical textbook

\begin{tabular}{|l|c|c|c|}
\hline $\begin{array}{l}\text { If you own a tablet... As far as required class textbooks are } \\
\text { considered, do you prefer using e-textbooks (digital format) to } \\
\text { a physical textbook (print) on your tablet? }\end{array}$ & $\begin{array}{c}\text { TC } \\
\text { (N=81) }\end{array}$ & $\begin{array}{c}\text { RMU } \\
\text { (N=45) }\end{array}$ & $\begin{array}{c}\text { Average } \\
\text { (N=126) }\end{array}$ \\
\hline Yes, I prefer using e-textbooks on my tablet over a physical book & $27.20 \%$ & $44.40 \%$ & $35.80 \%$ \\
\hline No, I prefer using physical book for my required class textbook & $50.60 \%$ & $42.20 \%$ & $46.40 \%$ \\
\hline Not sure/Undecided & $22.20 \%$ & $13.30 \%$ & $17.75 \%$ \\
\hline
\end{tabular}

\section{CONCLUSIONS}

This study provides practical insights for the field of computer information systems by exploring e-book and TPC usage among college students. The eight research questions in this exploratory study found the following statistics and some were significant.

Main Intent/Main Purpose: RQ3: Do students feel e-textbooks have a positive effect on their learning? $37 \%$ of college students feel e-textbooks have a positive effect on their learning; $41 \%$ did not notice a difference.

Four additional objectives were part of this study and the results are as follows:

Objective 1: RQ1: $34 \%$ of college students have purchased an e-textbook.

Significant Finding: RQ2: 55\% of college students primarily use e-textbooks on their laptops.

Objective 2: Significant Finding: RQ 4, 5, and 6, determined that "yes," tablets help students in education.

RQ4: $\quad 73 \%$ of college students feel tablets are valuable for education purposes.

RQ5: $\quad 47 \%$ of college students feel tablets help them study more efficiently.

RQ6: $\quad 40 \%$ of college students believe that tablets help them perform better in their classes.

Objective 3: Significant Finding: RQ7: 59\% of college students feel tablets will hold their textbooks and replace physical textbooks with the next five years.

Objective 4: RQ8: $36 \%$ of college students prefer using an e-textbook on their tablet to a physical textbook. 
Additional findings from the 2013 survey about tablets and purchasing textbooks were significant. Appendix C contains Tables 12-18, which shows the data about the following additional findings.

\section{Leisure Reading}

Calculating and analyzing this data was unnecessary because the responses were identical at both institutions; $38 \%$ of college students have purchased an e-book for leisure reading. In comparing RQ1 (34\% purchased an e-textbook for classes) to this this finding ( $38 \%$ purchased an e-book for leisure reading), the researcher concluded that $36 \%$ of the population have purchased a digital book.

- What percentage of college students has purchased an e-book(s) for leisure reading (fun)? $38 \%$ of college students have purchased an e-book for leisure reading.

- Do students prefer a physical book for leisure reading to an e-book? $42 \%$ of college students prefer a print book to an e-book for leisure reading.

\section{Professors - Significant Finding}

- Do you feel that professors should integrate tablet-based activities into their courses? $49 \%$ of college students feel professors should integrate tablet-based activities into their courses.

\section{Tablet Ownership}

- Do you own/have a tablet? $39 \%$ of college students own a tablet

- Select your basic tablet brand name? $42 \%$ of college students own an iPad tablet

\section{Thiel College - Bundle - Significant Finding}

- Do you think Thiel College should bundle both a laptop and tablet as part of the laptop initiative program? $69 \%$ of college students felt the college should bundle a tablet with their laptop

- If Thiel College distributed both a laptop and tablet, would you purchase e-textbooks for your tablet to use in your classes? $66 \%$ of college students would purchase e-textbooks to use in their classes

Overall, the results of this study should be used to inform the information systems community and individuals working in education because students' learning and study habits will change dramatically within the next five years due to the majority owning an e-reader, purchasing e-textbooks, and knowing that these two technologies can positively impact their education. The current generation of users is considered screenagers, which means these two technologies are effortless for them to use. This exploratory research study found that $36 \%$ of the population has purchased a digital book and 39\% own an e-reader, the use of Internet-based electronics is growing significantly.. With this technology increase, one could also surmise that the use of Wi-Fi and the Internet has also increased. The researcher offers two suggestions in light of this research. First, from a computer security perspective, the researcher strongly suggests that individuals use virus protection software and heed caution when using the Internet and web-based electronics. Second, from a psychological perspective, a constant digital connection exhausts emotional energy, drains attention span, and depletes physical strength. Therefore, to help counter act the effects of a constant digital connection, the researcher also suggests that individuals attain eight hours of sleep nightly, exercise regularly, and eat a well-balanced diet. Achieving these three suggestions will keep an individual's desire and stamina high in order to persevere through life.

\section{FUTURE RESEARCH}

Future research needs be conducted on learning styles using the media (e-textbooks and e-readers) discussed in this paper, as well as the potential of e-text to save students money. Furthermore, future research should also be conducted by linking this research to TAM. If further research on TAM would be conducted, the data collected could prove that e-readers and e-textbooks are becoming accepted because the technology can enhance a student's performance in classes. Finally, future research has been launched using the same survey instrument to collect data about smart phones. 


\section{REFERENCES}

1. Abram, S. (2010, May). Thinking about e-books. MultiMedia \& Internet@Schools, 17(3), 18-19. Retrieved September 14, 2010, from Research Library.

2. Almanac of Higher Education. (2013). The Chronicle of Higher Education. Retrieved March 6, 2014, from https://chronicle.com/article/College-Students-Attitudes/140759/.

3. Blackwell, C. (2010, Aug 18). Literature, literally at your fingertips! La Prensa Retrieved from http://search.proquest.com/docview/748740519?accountid=12085.

4. Brittany, A. C. (2012, Jan 06). College study: E-books falling flat. The Daily Camera. Retrieved from http://search.proquest.com/docview/916568206?accountid=12085.

5. Carr, D. F. (2013). College E-textbook adoption hinges on savings. Informationweek Online. Retrieved from http://search.proquest.com/docview/1403439718?accountid=12085.

6. Daniel, D. B., \& Woody, W. D. (2013). E-textbooks at what cost? Performance and use of electronic v. print texts. Computers \& Education, 62, 18-23.

7. Davis, F. (1989). "Perceived usefulness, perceived ease of use, and user acceptance of information technology," MIS Quarterly, 13(3), 319-340.

8. Google Editions: a history of e-books. (2010, December 2). The Telegraph. Retrieved March 4, 2014, from http://www.telegraph.co.uk/technology/google/8176510/Google-Editions-a-history-of-ebooks.html.

9. Haag, S., \& Cummings, M. (2010). Chapter 5 - Electronic Commerce. Management information systems for the information age (8th ed., p. 147). New York: McGraw-Hill Irwin.

10. Hawkins, D. T. (2000). "Electronic books: a major publishing revolution." Online 24(4), pp.14-28 (online). Retrieved February 17, 2001 from ProQuest (database). Bell \& Howell.

11. Healy, L. G. (2010, September 13). The effect of e-readers on young people is enormous. Spartanburg Herald Journal. Retrieved September 14, 2010, from ABI/INFORM Dateline. (Document ID: 2136366881).

12. Jesse, G. (2013). LIKE, TWEET, OR PIN: COLLEGE STUDENTS AND THEIR CURRENT USE OF SOCIAL MEDIA. Issues in Information Systems, 14(1), 403-414.

13. Manley, L., \& Holley, R. P. (2012). History of the Ebook: The Changing Face of Books. Technical Services Quarterly, 29(4), 292-311.

14. Mealer, C.K., Morgan, P.J. \& Williams, C.W. (2011, March 31). eReaders in Higher Education. The University of Alabama. http://bama.ua.edu/ ckmealer/MealerEport/EReaders.pdf, 17-18.

15. Moore, J. C. (2010, 12 January). State law requires digital college textbooks by 2020. McClatchy - Tribune Business News. Retrieved September 14, 2010, from ABI/INFORM Dateline.

16. Murray, M., \& Perez, J. (2011). E-Textbooks Are Coming: Are We Ready? Issues in Informing Science and Information Technology (IISIT), 8, 49-60. Retrieved March 6, 2014, from http://iisit.org/Vol8/IISITv8p049060Murray307.pdf.

17. E-reader. (2014, April). In Oxford English Dictionary online. Retrieved from http://www.oed.com.ezproxy.liberty.edu:2048/view/Entry/377403?redirectedFrom=e-reader\#eid.

18. Tablet Computer. (2014, April). In Oxford English Dictionary online. Retrieved from http://www.oed.com.ezproxy.liberty.edu:2048/view/Entry/196808?redirectedFrom=tablet+pc\#eid124984127.

19. Tablet PC. (2014, April). In Oxford English Dictionary online. Retrieved from http://www.oed.com.ezproxy.liberty.edu:2048/view/Entry/196808?redirectedFrom=tablet+pc\#eid124984127.

20. Paxhia, S. (2011). Book Industry Study Group. Retrieved March 6, 2014, from https://www.bisg.org/docs/Paxhia_Steve_AM.

21. Roscorla, T. (2013, Jul 18). E-textbooks report questions cost savings. McClatchy - Tribune Business News. Retrieved from http://search.proquest.com/docview/1401483494? accountid=12085.

22. Simon, Eric. (2001, Winter). Electronic Textbooks: A Pilot Study of Student E-Reading Habits. Future of Print Media Journal. http://bogliolo.eci.ufmg.br/downloads/TGI061\%20ERIC\%20SIMON\%20Electronic\%20Textbooks.pdf

23. Snodgrass, P. (2012, 04). E-textbooks' fast growth. Firehouse, 37, 96-98,100,102-103. Retrieved from http://search.proquest.com/docview/1237625469?accountid=12085.

24. Weber, P. (2014, January 3). Texas library offers glimpse of bookless future. The Associated Press. Retrieved March 30, 2014, from http://bigstory.ap.org/article/texas-library-offers-glimpse-bookless-future. 


\section{APPENDIX A}

Participation Statistics for Thiel College (TC) and Robert Morris University (RMU)

\begin{tabular}{|l|r|r|r|}
\hline & \multicolumn{1}{|c|}{$\begin{array}{c}\text { TC } \\
\text { (Entire Population) }\end{array}$} & $\begin{array}{c}\text { RMU } \\
\text { (School of C \& I.S.) }\end{array}$ & $\begin{array}{c}\text { Average } \\
\text { Participation }\end{array}$ \\
\hline Total Enrollment & 981 & 931 & 1912 \\
\hline Consent Agreement \& $>18$ years old & 291 & 104 & 395 \\
\hline Percent of population surveyed & $\mathbf{3 0 \%}$ & $\mathbf{1 1 \%}$ & $\mathbf{2 1 \%}$ \\
\hline
\end{tabular}

Demographic Statistics for Robert Morris University (RMU) and Thiel College (TC)

\begin{tabular}{|l|l|r|}
\hline Age & RMU & TC \\
\hline 18 & $6.8 \%$ & $17.2 \%$ \\
\hline 19 & $15.5 \%$ & $27.0 \%$ \\
\hline 20 & $17.5 \%$ & $26.0 \%$ \\
\hline 21 & $18.4 \%$ & $16.6 \%$ \\
\hline 22 & $6.8 \%$ & $8.8 \%$ \\
\hline 23 & $3.9 \%$ & $0.3 \%$ \\
\hline 24 & $1.0 \%$ & $0.3 \%$ \\
\hline $25-30$ & $15.5 \%$ & $0.3 \%$ \\
\hline$>30$ & $14.6 \%$ & $2.4 \%$ \\
\hline
\end{tabular}

\begin{tabular}{|c|c|c|}
\hline Gender & RMU & TC \\
\hline Male & $64.7 \%$ & $40.1 \%$ \\
\hline Female & $35.3 \%$ & $59.2 \%$ \\
\hline Race & RMU & TC \\
\hline $\begin{array}{l}\text { White, } \\
\text { Caucasian }\end{array}$ & $91.2 \%$ & $85.9 \%$ \\
\hline $\begin{array}{l}\text { White, non- } \\
\text { Hispanic }\end{array}$ & $1.0 \%$ & $2.8 \%$ \\
\hline $\begin{array}{l}\text { African- } \\
\text { American }\end{array}$ & $5.9 \%$ & $6.0 \%$ \\
\hline Hispanic & $0.0 \%$ & $2.5 \%$ \\
\hline $\begin{array}{l}\text { Asian-Pacific } \\
\text { Islander }\end{array}$ & $1.0 \%$ & $0.4 \%$ \\
\hline
\end{tabular}

\begin{tabular}{|l|l|c|}
\hline GPA & RMU & TC \\
\hline $\mathrm{A}(4.0 \&>)$ & $28.2 \%$ & $17.1 \%$ \\
\hline $\mathrm{A} / \mathrm{B}(3.5)$ & $40.8 \%$ & $27.2 \%$ \\
\hline $\mathrm{B}(3.0)$ & $22.3 \%$ & $28.9 \%$ \\
\hline $\mathrm{B} / \mathrm{C}(2.5)$ & $8.7 \%$ & $21.3 \%$ \\
\hline $\mathrm{C}(2.0)$ & $0.0 \%$ & \\
\hline & & $2.4 \%$ \\
$\mathrm{C} / \mathrm{D}(1.5)$ & & $1.4 \%$ \\
\hline & $0.0 \%$ & \\
$\mathrm{D}(1.0)$ & & $0.3 \%$ \\
\hline Don't know & $0.0 \%$ & $0.7 \%$ \\
\hline
\end{tabular}

\begin{tabular}{|l|r|}
\hline \multicolumn{2}{|c|}{ TC - Response \% by Major } \\
\hline Accounting & $7.6 \%$ \\
\hline Art & $0.3 \%$ \\
\hline Binary Engineering & $1.7 \%$ \\
\hline Biology & $14.9 \%$ \\
\hline Business & $8.7 \%$ \\
\hline Chemistry & $3.5 \%$ \\
\hline Communications & $5.9 \%$ \\
\hline Computer Science & $3.1 \%$ \\
\hline Culinary Arts & $1.0 \%$ \\
\hline Criminal Justice Studies & $6.3 \%$ \\
\hline Elementary Education & 12.1 \\
\hline English & $2.1 \%$ \\
\hline Environmental Chemistry or Science & $1.4 \%$ \\
\hline History & $3.1 \%$ \\
\hline Management Information Systems & $1.0 \%$ \\
\hline Mathematics, Actuarial Studies & $1.4 \%$ \\
\hline Medical Technology & $0.3 \%$ \\
\hline Neuroscience & $1.0 \%$ \\
\hline Physics & $1.0 \%$ \\
\hline Political Science & $3.1 \%$ \\
\hline Psychology & $10.4 \%$ \\
\hline Religion & $0.3 \%$ \\
\hline Sociology & $2.1 \%$ \\
\hline Web Development & $2.8 \%$ \\
\hline Undecided & $1.7 \%$ \\
\hline
\end{tabular}

\begin{tabular}{|l|l|}
\hline \multicolumn{2}{|c|}{ RMU - Response \% by Major } \\
\hline Advertising & $1.9 \%$ \\
\hline Communication & $10.7 \%$ \\
\hline Competitive Intelligence Systems & $2.9 \%$ \\
\hline Computer Information Systems & $38.8 \%$ \\
\hline Corporate Communication & $1.0 \%$ \\
\hline Cyber Forensics and Information Security & $15.5 \%$ \\
\hline Secondary Education (Grades 7 - 12) & $1.0 \%$ \\
\hline Engineering & $1.0 \%$ \\
\hline English & $3.9 \%$ \\
\hline Graphic Design & $1.0 \%$ \\
\hline Information Sciences & $5.8 \%$ \\
\hline Journalism & $3.9 \%$ \\
\hline Mathematics & $1.9 \%$ \\
\hline Organizational Leadership* & $6.8 \%$ \\
\hline Professional Communications and Info. Sys. & $1.0 \%$ \\
\hline Software Engineering & $2.9 \%$ \\
\hline
\end{tabular}




\section{APPENDIX B}

Davis [4] Technology Acceptance Model (TAM)

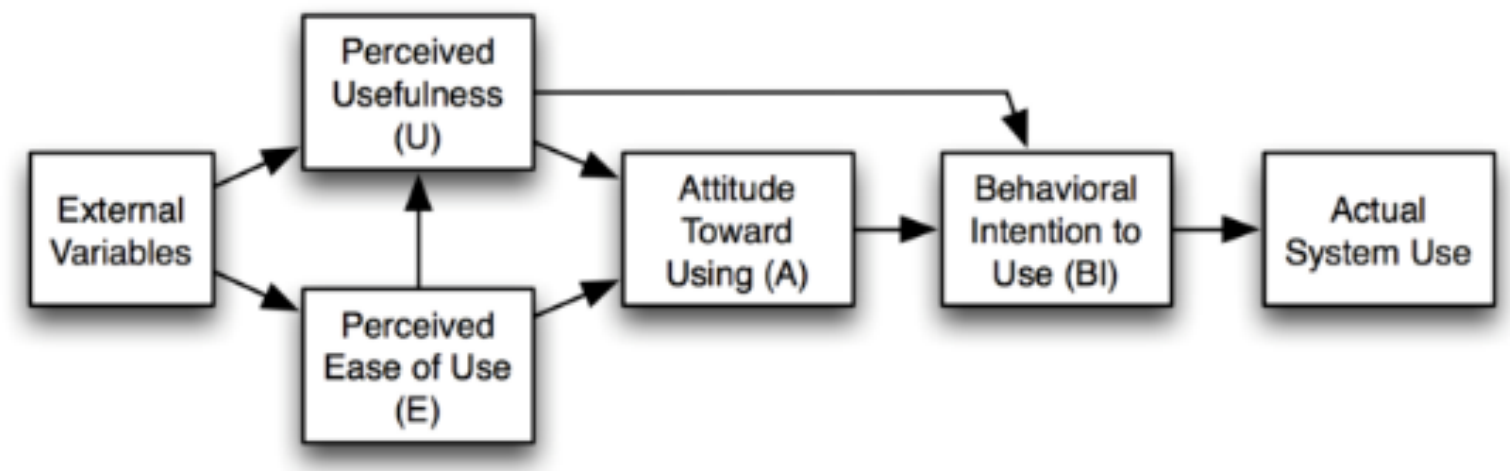

\section{APPENDIX C}

Additional Findings - Average percentages between the two institutions

Table 12. Percentage of college students that have purchased e-book(s) for leisure reading (fun)

\begin{tabular}{|c|c|c|}
\hline Have you purchased an e-book(s) for leisure reading (fun)? & $\begin{array}{c}\text { TC } \\
(\mathrm{N}=274)\end{array}$ & $\begin{array}{c}\text { RMU } \\
(\mathrm{N}=94)\end{array}$ \\
\hline Yes & $38.30 \%$ & $38.30 \%$ \\
\hline No & $61.70 \%$ & $61.70 \%$ \\
\hline
\end{tabular}

Table 13. Students who prefer a physical book for leisure reading to an e-book

\begin{tabular}{|l|c|c|c|}
\hline $\begin{array}{l}\text { Do you prefer a physical book (hardback or paperback) to an } \\
\text { e-book (digital) for leisure (fun) reading? }\end{array}$ & $\begin{array}{c}\text { TC } \\
(\mathrm{N}=105)\end{array}$ & $\begin{array}{c}\text { RMU } \\
(\mathrm{N}=36)\end{array}$ & $\begin{array}{c}\text { Average } \\
\text { (N=141) }\end{array}$ \\
\hline Yes, I prefer a physical book over an e-book for leisure reading & $37.10 \%$ & $47.20 \%$ & $42.15 \%$ \\
\hline No, I prefer an e-book over a physical book for leisure reading & $18.10 \%$ & $19.40 \%$ & $18.75 \%$ \\
\hline Same/No difference in preference & $43.80 \%$ & $33.30 \%$ & $38.55 \%$ \\
\hline Not Sure/Undecided & $1.00 \%$ & $0.00 \%$ & \\
\hline
\end{tabular}

Table 14. Students who feel that professors should integrate tablet-based activities into their courses

\begin{tabular}{|l|c|c|c|}
\hline $\begin{array}{l}\text { Do you feel that professors should integrate tablet-based } \\
\text { activities into their courses? }\end{array}$ & $\begin{array}{c}\text { TC } \\
(\mathrm{N}=270)\end{array}$ & $\begin{array}{c}\text { RMU } \\
(\mathrm{N}=93)\end{array}$ & $\begin{array}{c}\text { Average } \\
(\mathrm{N}=363)\end{array}$ \\
\hline Yes & $52.20 \%$ & $46.20 \%$ & $49.20 \%$ \\
\hline No & $22.20 \%$ & $30.10 \%$ & $26.15 \%$ \\
\hline Not sure/Undecided & $25.60 \%$ & $23.70 \%$ & $24.65 \%$ \\
\hline
\end{tabular}

Table 15. Percentage of students who own/have a tablet

\begin{tabular}{|l|c|c|c|}
\hline Do you own/have a tablet? & $\begin{array}{c}\text { TC } \\
(\mathrm{N}=271)\end{array}$ & $\begin{array}{c}\text { RMU } \\
(\mathrm{N}=94)\end{array}$ & $\begin{array}{c}\text { Average } \\
(\mathrm{N}=365)\end{array}$ \\
\hline Yes & $30.60 \%$ & $47.90 \%$ & $39.25 \%$ \\
\hline No & $69.40 \%$ & $52.10 \%$ & $60.75 \%$ \\
\hline
\end{tabular}


Table 16. Students' basic tablet brand names

\begin{tabular}{|l|l|l|l|}
\hline Select your basic tablet brand name? & $\begin{array}{c}\text { TC } \\
(\mathrm{N}=84)\end{array}$ & $\begin{array}{c}\text { RMU } \\
(\mathrm{N}=51)\end{array}$ & $\begin{array}{c}\text { Average } \\
(\mathrm{N}=135)\end{array}$ \\
\hline Apple - iPad & 46.25 & 37.78 & 42.015 \\
\hline Amazon - Kindle & $25.00 \%$ & $13.33 \%$ & $19.17 \%$ \\
\hline Barnes \& Noble - Nook & $8.75 \%$ & $8.89 \%$ & $8.82 \%$ \\
\hline Samsung - Galaxy & $6.25 \%$ & $8.89 \%$ & $7.57 \%$ \\
\hline Google - Nexus & $2.50 \%$ & $13.33 \%$ & $7.92 \%$ \\
\hline Polaroid & $2.50 \%$ & $0.00 \%$ & $1.25 \%$ \\
\hline Microsoft - Surface & $0.00 \%$ & $6.67 \%$ & $3.33 \%$ \\
\hline Asus - Transformer Pad Infinity & $1.25 \%$ & $6.67 \%$ & $3.96 \%$ \\
\hline Don't Know & $7.50 \%$ & $4.44 \%$ & $5.97 \%$ \\
\hline
\end{tabular}

Table 17. Should Thiel College bundle both a laptop and tablet?

\begin{tabular}{|l|c|}
\hline $\begin{array}{l}\text { Do you think Thiel College should bundle both a laptop and } \\
\text { tablet as part of the laptop initiative program? }\end{array}$ & $\begin{array}{l}\text { Response } \\
\text { Percent } \\
(\mathrm{N}=270)\end{array}$ \\
\hline Yes & $69.30 \%$ \\
\hline No & $19.60 \%$ \\
\hline Not sure/Undecided & $11.10 \%$ \\
\hline
\end{tabular}

Table 18. If Thiel provided a tablet, would you purchase e-textbooks for your tablet to use in your classes?

\begin{tabular}{|l|l|}
\hline $\begin{array}{l}\text { If Thiel College distributed both a laptop and tablet, would } \\
\text { you purchase e-textbooks for your tablet to use in your } \\
\text { classes? }\end{array}$ & $\begin{array}{l}\text { Response } \\
\text { Percent } \\
\text { (N=270) }\end{array}$ \\
\hline Yes & $65.60 \%$ \\
\hline No & $21.10 \%$ \\
\hline Not sure/Undecided & $13.30 \%$ \\
\hline
\end{tabular}

